\title{
Anxiety, Depression and Somatization: The Pandemic No One Sees
}

\author{
Alondra Chira B, ${ }^{1 *}$ José M Vela Ruiz ${ }^{2}$ \\ ${ }^{1}$ Human Medicine Student, Biomedical Sciences Research Institute, Ricardo Palma University, Peru \\ ${ }^{2}$ Master in health services management, Biomedical Sciences Research Institute, Ricardo Palma University, Peru
}

\section{Editorial}

The pandemic by the Covid-19 started a little over a year ago, in December 2019 in the city of Wuhan, China from a mutant strain of corona-virus the SARS-CoV-2, which was expanding rapidly across the rest of the countries and continents, in such a way that, in March 2020, the World Health Organization (WHO) declared a new global pandemic. ${ }^{1}$ Due to the rapid transmission of this infection, the majority of governments worldwide opted, as one of the main measures to stop the pandemic, the application of mandatory quarantines. These quarantines, although at first, they were completely strict and helped to stop to a certain extent the high rates of infections, had a negative impact on the mental health of the majority of the world's population, having as main symptoms: depression, anxiety, anguish, among others, in addition to a somatization of all these symptoms, all of them related to the fear of contagion. ${ }^{2}$ One of the groups most affected by the aforementioned has been students, particularly university students, since these, in addition to the fear of contagion and everything that the COVID-19 disease implies, have academic overload and responsibilities, which according to research, ${ }^{2}$ generate a level of extra anxiety, tension, depression, in addition to somatization due to increased activity of the autonomic nervous system, presenting symptoms such as tachycardia, chest tightness, epigastric discomfort and restlessness.

Multiple studies on this issue have been carried out worldwide since the confinement due to the pandemic began, of which one of them was in China, ${ }^{3}$ where it was shown that the vast majority of participants in this study presented moderate to severe symptoms. Severe anxiety, depression and stress, these statistics being more evident in female students. On the other hand, a study in Spain, ${ }^{4}$ concluded that the study group of people between 18 25 years old, presented much higher levels of anxiety, depression and stress, compared to people over 60 years. Likewise, in Mexico, ${ }^{5}$ the same was done when studying a group of students, giving as a result that, although moderate to severe symptoms of depression and anxiety occur more frequently in male students, female students present higher scores for psychosomatic symptoms. Meanwhile a to research in Peru, in the cities of Trujillo and Chimbote, it was found that the same as in studies in China, the fact that classes are postponed, are remote, new methods of virtual teaching and connectivity facilities are some of the causes that affect the mental health of university students in our country. ${ }^{6}$ In addition to the aforementioned, it was shown that female students presented higher peaks in terms of symptoms and their severity, this explained by the female sex tendency to deal with multiple demands, which leads to a decrease in their autonomy and inattention to oneself. ${ }^{6}$

Due to the before mentioned, it can be concluded that the COVID - 19 quarantine has affected university students, in different measures according to sex or socioeconomic characteristics. However, I believe that, as in other countries such as China or South Korea, psychological help measures should be implemented through free hotlines, in addition to sharing strategies, brochures and guides through government and university institutions.

\section{Acknowledgments}

Authors participated in the generation, collection of information, writing and final version of the original article.

\section{Funding}

Self-financed.

\begin{tabular}{|l|l|}
\hline \hline Quick Response Code: & *Corresponding author: Alondra Stefany Chira Bardales, Human Medicine Student, Biomed- \\
ical Sciences Research Institute, Ricardo Palma University, Av. Benavides 5440, Santiago de \\
Surco, Lima 33, Peru \\
Received: 03 July, $2021 \quad$ Published: 30 July, 2021
\end{tabular}




\section{Conflict of Interest}

Authors declare no conflicts of interest in the publication of this article.

\section{References}

1. Maguiña C, Gastelo R, Tequen A. The new Coronavirus and Covid-19 pandemic. Rev Med Hered. 2020;31(2):125-131.

2. Vivanco A, Saroli D, Caycho T, et al. Ansiedad por Covid-19 y salud mental en universitarios. Rev Inv Psicol. 2020;23(2):197-215.
3. Chen $\mathrm{Q}$, Liang $\mathrm{M}$, Li $\mathrm{Y}$, et al. Mental health care for medical staff in China during the COVID-19 outbreak. The Lancet Psychiatry. 2020;7(4):e15-e16.

4. Ozamiz N, Dosil M, Picaza M, et al. Niveles de estrés, ansiedad y depresión en la primera fase del brote del COVID-19 en una muestra recogida en el norte de España. CadSaúde Pública. 2020;36(4):e00054020.

5. Gonzáles N, Tejeda A, Espinoza C, et al. Impacto psicológico en estudiantes universitarios mexicanos por confinamiento durante la pandemia por Covid-19. 2020.

6. Vidal A. Ansiedad por COVID - 19 y Salud Mental en Estudiantes Universitarios de las ciudades de Trujillo y Chimbote. 